\title{
SOME AGRONOMICAL PRACTICES FOR IMPROVING TOMATO (Lycopersicon esculentum, Mill) PRODUCTIVITY UNDER HIGH TEMPERATURE CONDITIONS. El-Sayed, Hala A. ${ }^{\text {; }}$ M. M. B. Shokr ${ }^{2}$ and M. A. A. El- Sherbini ${ }^{2}$ 1. Veg. and Flori. Dept., Fac. of Agric., Mans. Univ., Egypt. \\ 2. Veg. Res. Dept., Hort. Res. Inst., Agric. Res. Center, Giza, Egypt.
}

\begin{abstract}
Two field experiments were conducted at EL-Baramon Research Station, Dakahlia Governorate, Egypt. during summer seasons of 2007 and 2008 to study the effect of some foliar applications, i.e., calcium at $2000 \mathrm{mg} / \mathrm{L}$, magnesium at 2000 $\mathrm{mg} / \mathrm{L}$, zinc at $100 \mathrm{mg} / \mathrm{L}$, boron at $50 \mathrm{mg} / \mathrm{L}$, selenium at $50 \mathrm{mg} / \mathrm{L}+$ vitamin $\mathrm{E}$ at 150 $\mathrm{mg} / \mathrm{L}$, yeast extract at $100 \mathrm{ml} / \mathrm{L}$ and salicylic acid at $100 \mathrm{mg} / \mathrm{L}$ on vegetative growth, flowering and fruit yield of Castle Rock and Super Strain-B tomato cvs under high temperature conditions. Seedlings were transplanted on 9 th and $15^{\text {th }}$ of May in the first and the second seasons, respectively.

The results showed that Castle Rock plants had more leaves and branches, heaviest fresh and dry weight and gave the best flowering parameters, i.e., number of clusters/plant, number of flowers/plant, fruit set percentage (\%) and total fruit yield(ton/fed.) compared with Super Strain-B cultivar which had the longest plants in the two seasons. Moreover, all foliar applications (Ca, Mg, Zn, B, Se + VE, Yeast and $\mathrm{SA}$ ) increased plant height, number of leaves and branches/plant and fresh and dry weight of leaves and increased all studied flowering parameters and total fruit yield(ton/fed.) compared to the control treatment. However, Super Strain-B plants sprayed with SA had the longest plants, while Castle Rock plants treated with SA and $\mathrm{B}$ gave more leaves and branches, respectively. Moreover, plants of Castle Rock sprayed with B had the most records in fresh and dry weight, fruit setting (\%), number of fruits/plant and total fruit yield(ton/fed.). whereas Castle Rock plants treated with $\mathrm{Ca}$ had more clusters and flowers/plant.

From the obtained results it could be concluded that spraying Castle Rock cv plants with boron at $50 \mathrm{mg} / \mathrm{L}$, calcium at $2000 \mathrm{mg} / \mathrm{L}$, salicylic acid at $100 \mathrm{mg} / \mathrm{L}$ and selenium at concentration of $50 \mathrm{mg} / \mathrm{L}$ mixed with vitamin $\mathrm{E}$ at concentration of 150 $\mathrm{mg} / \mathrm{L}$ as foliar application three times, i.e., 15 days after transplanting then repeated each 15 days interval improve tomato vegetative growth, flowering and fruit yield(ton/fed.)
\end{abstract}

\section{INTRODUCTION}

Tomato (Lycopersicon esculentum, Mill) represents one of the most important vegetable crops all over the world, due to its high nutritional value and various uses. In Egypt it is considered the first rank among the vegetable crops for local consumption and exportation. High temperature in summer seasons is one of the most important abiotic factors affect tomato plant growth and fruit set (Rivero et al., 2004). It was reported that the reproductive developments in tomato was more sensitive to high temperatures than the vegetative developments (Soylu and Çömlekçioğlu, 2009). The direct injuries due to high temperature include protein denaturation and aggregation as well as increased fluidity of membrane lipids. Indirect or slower heat injuries include inactivation of enzymes in 
chloroplast and mitochondria, inhibition of protein synthesis, protein degradation and loss of membrane integrity (Howarth, 2005). These injuries eventually lead to starvation, inhibition of growth, reduced ion flux, production of toxic compounds and reactive oxygen species (ROS) (Schöffi et al., 1999 and Howarth, 2005). These ROS $\left(\mathrm{H}_{2} \mathrm{O}_{2}, \mathrm{OH}, \mathrm{O}_{2}-, \ldots\right)$ damaged chloroplast, reduced carbohydrate synthesis and exportation and hastened oxygen senescence, attack cell membranes, led to their degradation and leakage of cell solutes, denaturation of proteins and enzymes, damage of nucleic acids, degradation of chlorophyll and suppression of all metabolic processes and finally senescence and death of cells and tissues (Dicknson et al., 1991). The most noticeable effect of high temperatures on reproductive processes in tomato is the production of an exerted style (i.e., elongation of stigma beyond the anther cone), which may prevent self-pollination (Kinet and Peet, 1997).

Many studies pointed out that antioxidant substances increase plant tolerance against adverse effects of heat stress. In this respect, foliar applications of some nutrients, i.e., $\mathrm{Ca}, \mathrm{Mg}, \mathrm{B}, \mathrm{Zn}$, and $\mathrm{Se}+\mathrm{V}$. E as well as SA and yeast extract as antioxidant substances were used to improve growth and flowering of tomato and protect it against adverse effects of oxidative stress. These substances intercept free radicals and protect cell from the oxidative damage that lead to aging and diseases (Karadeniz et al., 2005). Calcium might act as a second messenger in some signaling pathway limiting heat-induced oxidative damage (Larkindale and Knight, 2002). It involved in plant tolerance to heat stress by regulating antioxidant metabolism (Jiang and Hung, 2001). Ca and Mg known to be activated H+ATP-ase membrane pump the key active machine and site for cations transport and retention that attributed to alleviation adverse effects of environmental conditions (Palta, 1990).

Also, boron has a role in cell division, hence promoted root elongation and shoot growth via activation the synthesis of RNA and protein within meristematic tissue (Albert and Wilson, 1961; Albert, 1965 and Sarin and Sadgopal, 1967). Zinc act as antioxidants, protect the chloroplasts against the formation of toxic ROS levels thereby prevent degradation of pigments and inhibits the photoxidation of pigments that arise under heat stress condition (Domingo et al., 1990 ; Brown et al., 1993). Furthermore, selenium play an important regulatory role in improving the tolerance of plants to high temperature stress through increasing chlorophyll content and activating antioxidant enzymes (Shang Qing Mao et al., 2005). Vitamin E is highly effective antioxidant at the membrane site (Hess, 1983).

Concerning Salicylic acid it is a signal transduction or messenger (Klessing and Malamy, 1994). Yeast can induce thermotolerance due to its content of heat shock proteins (HSPS) (Weiderrecht et al., 1988). It is a natural source of many growth substances (thiamine, viboflavin, niacin, pyridoxine Hel, panthenate, bioten, cholin, folic acid and vit.B 12) and most nutritional elements ( $\mathrm{Na}, \mathrm{Ca}, \mathrm{Fe}, \mathrm{Mg}, \mathrm{K}, \mathrm{P}, \mathrm{S}, \mathrm{Zn}, \mathrm{Si}$ ) as well as organic compounds (protein, carbohydrate, nucleic acids and lipids (Nagodawithana, 1991). The objective of this study was to evaluate the effect of foliar spraying of some antioxidants on growth, flowering and fruit yield of tomato plants under high temperature stress. 


\section{MATERIALS AND METHODS}

Two field experiments were carried out at EL-Baramon Research Station, Dakahlia Governorate, Egypt during summer seasons of 2007 and 2008 to study the effect of foliar applications with calcium, magnesium, boron, zinc, selenium + vitamin E, salicylic acid, yeast extract on plant growth, flowering of tomato (Lycopersicon esculentum, Mill) Castle Rock and Super Strain-B cultivars. The monthly average temperature during seasonal growth 2007 and 2008 are shown in table (1). Seedlings were transplanted on 9 th and $15^{\text {th }}$ of May in the first and the second seasons, respectively. The experimental layout was split-plot system in a randomized complete blocks design with three replicates, i.e., the main plots were cultivars (Castle Rock and Super Strain-B), while the sub-plots were the foliar applications. The sub-plot area was $9.6 \mathrm{~m}^{2}$ ( 2 ridges, each $4 \mathrm{~m}$ long and $120 \mathrm{~cm}$ width). Tomato seedlings were transplanted at $30 \mathrm{~cm}$ apart on one side of ridge.

Plants of the two cvs were sprayed three times, 15 days after transplanting and repeated each 15 days with solutions of the following treatments:

1 - Ca at $2000 \mathrm{mg} / \mathrm{L}$ in form of Ca-citrate (25\%).

2- $\mathrm{Mg}$ at $2000 \mathrm{mg} / \mathrm{L}$ in form of Mg-citrate (14\%).

$3-\mathrm{Zn}$ at $100 \mathrm{mg} / \mathrm{L}$ in form of $\mathrm{Zn}$-citrate (12\%).

$4-\mathrm{B}$ at $50 \mathrm{mg} / \mathrm{L}$ in form of boric acid (16\%).

5- Se + Vitamin E (selenium at concentration of $50 \mathrm{mg} / \mathrm{L}$ in form of sodium selinate + vitamin $E$ at concentration of $150 \mathrm{mg} / \mathrm{L})$.

6 - Yeast extract at $(100 \mathrm{ml} / \mathrm{L})$.

7- SA at $100 \mathrm{mg} / \mathrm{L}$ in form of salicylic acid (95\%).

8- Control treatment.

The common recommended cultural practices for the commercial production of tomato were carried out whenever they were necessary.

At 65 days after transplanting five plants were randomly taken from each plot for determining the vegetative growth parameters, i.e., plant height, number of leaves and branches/plant and fresh and dry weight (gm). The flowering parameters recorded were: number of clusters/plant, number of flowers/plant and fruit set percentage (\%).

Fruit set $\%=\frac{\text { No. of fruits } / \text { plant }}{\text { No. of flowers/plant }} \times 100$

Fruit yield: number of fruits/plant and total yield (ton/fed.).

All collected data on plot basis were subjected to the statistical analysis according to the method mentioned by Snedecor and Cochran (1968). The data of treatment means were compared using least significant difference (LSD) method as mentioned by Gomez and Gomez (1984). 
Table (1): Monthly average maximum and minimum temperature during 2007 and 2008 seasons at experimental region. ${ }^{*}$

\begin{tabular}{|c|c|c|c|c|}
\hline \multirow{3}{*}{ Months } & \multicolumn{4}{|c|}{ Temperature $\left({ }^{\circ} \mathrm{C}\right)$} \\
\hline & \multicolumn{2}{|c|}{2007} & \multicolumn{2}{|c|}{2008} \\
\hline & Max. & Min. & Max. & Min. \\
\hline May & 31.37 & 17.17 & 31.39 & 16.39 \\
\hline June & 33.74 & 20.93 & 34.34 & 22.31 \\
\hline July & 34.33 & 23.33 & 33.68 & 23.33 \\
\hline August & 34.21 & 23.40 & 33.46 & 23.03 \\
\hline
\end{tabular}

* Data were taken by Shawa weather station.

\section{RESULTS AND DISCUSSION}

Vegetative growth characters:

Plant height and number of leaves and branches/plant:

Effect of cultivars:

Data presented in table (2) showed that Super Strain-B cultivar had higher values than Castle Rock cultivar only in plant height in both seasons, whereas Castle Rock cultivar was superior and higher than Super Strain-B on number of leaves and branches/plant.

The differences between the studied cultivars were significantly in plant height, number of leaves/plant in both seasons and in number of branches/plant in the second season. Similar results obtained by El-Desouky et al. (2000); Abdelmageed et al. (2003) and Glala et al. (2005) they showed that tomato cultivars differed significantly in vegetative growth habits.

Table (2): Effect of tomato cultivars and foliar applications on vegetative growth during 2007 (S1) and 2008 (S2) summer seasons.

\begin{tabular}{|c|c|c|c|c|c|c|c|c|c|c|c|}
\hline \multirow{2}{*}{\multicolumn{2}{|c|}{ Treatments }} & \multicolumn{2}{|c|}{$\begin{array}{c}\text { Plant } \\
\text { height(cm) }\end{array}$} & \multicolumn{2}{|c|}{$\begin{array}{c}\text { No. of } \\
\text { leaves/plant }\end{array}$} & \multicolumn{2}{|c|}{$\begin{array}{c}\text { No. of } \\
\text { branches/ } \\
\text { plant }\end{array}$} & \multicolumn{2}{|c|}{$\begin{array}{c}\text { Fresh } \\
\text { weight(gm) }\end{array}$} & \multicolumn{2}{|c|}{$\begin{array}{l}\text { Dry weight } \\
\text { (gm) }\end{array}$} \\
\hline & & $\mathbf{S} 1^{*}$ & S2 & S1 & S2 & S1 & S2 & S1 & S2 & S1 & S2 \\
\hline \multirow[b]{2}{*}{ डे } & Castle Rock & 66.16 & 727 & & & 2.56 & 13.78 & 463 & & & \\
\hline & $\begin{array}{l}\text { Super Strain- } \\
\text { B }\end{array}$ & 70.50 & 72.37 & 109.19 & 110.33 & 12.37 & 12.91 & 89.65 & .75 & 9.50 & 1.79 \\
\hline \multicolumn{2}{|r|}{ L.S.D. at $5 \%$} & 0 & 0.61 & 49 & .36 & IS & 15 & 2 & 0.98 & 0 & .52 \\
\hline \multirow{9}{*}{ 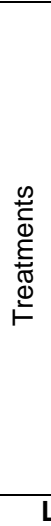 } & $\begin{array}{l}\mathrm{Ca} \text { at } 2000 \\
\mathrm{mg} / \mathrm{l}\end{array}$ & 69.00 & 70.83 & 113.75 & 118.00 & 13.00 & 13.66 & 468.43 & 490.41 & 90.80 & 94.27 \\
\hline & $\begin{array}{l}\mathrm{Mg} \text { at } 2000 \\
\mathrm{mg} / \mathrm{I}\end{array}$ & 67.83 & 69.08 & 112.79 & 115.62 & 12.16 & 13.50 & 406.87 & 424.83 & 80.52 & 36.09 \\
\hline & \begin{tabular}{|l|}
$\mathrm{Zn}$ at 100 \\
$\mathrm{mg} / \mathrm{l}$
\end{tabular} & 66.16 & 43 & 54 & 105.58 & 12.25 & 12.83 & 25 & .00 & 73.05 & 4.69 \\
\hline & $\begin{array}{l}\mathrm{B} \text { at } 50 \\
\mathrm{mg} / \mathrm{l}\end{array}$ & 69.83 & 2.11 & 115.91 & 116.75 & 13.50 & 14.50 & 490.18 & 499.83 & 91.62 & 93.83 \\
\hline & $\begin{array}{l}\text { Se at } 50 \mathrm{mg} / \mathrm{l} \\
+V . E 150 \mathrm{mg} / \mathrm{l}\end{array}$ & 68.83 & 70.50 & $\mid 111.87$ & 109.25 & 12.58 & 13.80 & 427.62 & 441.25 & 88.34 & 89.60 \\
\hline & \begin{tabular}{|l|}
$\begin{array}{l}\text { Yeast at } 100 \\
\mathrm{ml} / \mathrm{l}\end{array}$ \\
\end{tabular} & 66.75 & 68.54 & 1( & 105.04 & 11.66 & 12.50 & 3 & 41 & 70.34 & 64 \\
\hline & $\begin{array}{l}\text { SA at } 100 \\
\mathrm{mg} / \mathrm{l}\end{array}$ & 72 & 72.58 & 12 & 125.50 & 13.00 & 14.00 & 83 & 470.83 & 87.12 & 8.40 \\
\hline & & & & 10 & & 11. & 0 & 12 & & & \\
\hline & L.S.D. a & 1.0 & \begin{tabular}{|l|l|}
1.17 \\
\end{tabular} & 1.14 & 1.21 & 1.12 & 0.94 & 1.42 & 1.38 & 1.09 & $\begin{array}{ll}1.36 \\
\end{array}$ \\
\hline
\end{tabular}




\section{Effect of foliar applications:}

Data in table (2) clearly showed that all foliar treatments ( $\mathrm{Ca}, \mathrm{Mg}, \mathrm{Zn}$, $\mathrm{B}$, Se $+\mathrm{VE}$, Yeast and $\mathrm{SA}$ ) increased the values of vegetative growth parameters, i.e., plant height and number of leaves and branches/plant compared with the control treatment. The highest values of plant height and number of leaves/plant were obtained from salicylic acid application followed by boron and calcium applications, respectively in both seasons. Also, the results declared that boron application was the most superior treatment as for number of branches/plant in both seasons.

These results agreed with those of Khedr and Farid (2000); Hamsaveni et al. (2003); Manoj-Raghav and Sharma (2003); Oyinlola (2004); Abou-Aly (2005); Glala et al. (2005); Jayakumar et al. (2006); Jyolsna and Usha Mathew (2008); Patil et al. (2008) and Yildirim and Dursun (2009).

\section{Effect of interaction between tomato cultivars and foliar applications:}

The two cvs had superior responses to all treatments compared with control in the two seasons as shown in table (3). Super Strain-B cultivar had the longest plants when treated with SA followed by $\mathrm{B}$ and $\mathrm{Ca}$, while Castle Rock cv had more leaves and branches than Super Strain-B cv when sprayed with SA.

\section{Fresh and dry weight of plant:}

Effect of cultivars:

Data presented in table (2) indicated that there were significant differences between the two studied cultivars as for fresh and dry weight of tomato plants in the two growing seasons. However, Castle Rock cultivar surpassed Super Strain-B cultivar in this respect. Also, El-Desouky et al. (2000) found that tomato genotypes exhibited significant variations regarding their shoots fresh and dry weights. In general, tomato genotypes mostly showed different growth responses under stressful temperature of field conditions.

The evidenced fact is that the plant growth affected by genotype, therefore the studied cvs differed significantly in most plant growth characters under the same conditions.

\section{Effect of foliar applications:}

Data in table (2) clearly showed that all foliar treatments $(\mathrm{Ca}, \mathrm{Mg}, \mathrm{Zn}, \mathrm{B}, \mathrm{Se}+\mathrm{VE}$, Yeast and $\mathrm{SA})$ significantly increased the fresh and dry weight of tomato plants compared with the control, in both seasons. The most stimulatory and potent effects in diminshed order were of $B$ followed by $\mathrm{Ca}$ and $\mathrm{SA}$ treatments as for fresh weight, and $\mathrm{B}$, $\mathrm{Ca}$ and $\mathrm{Se}+\mathrm{VE}$ as for dry weight then SA, Mg, $\mathrm{Zn}$ and at least yeast extract, respectively. These results coincide with those of Amer (1981); Khedr and Farid (2000); Yadav et al. (2001); Abou-Aly (2005); Glala et al. (2005) and Jayakumar et al. (2006).

\section{Effect of interaction between tomato cultivars and foliar applications:}

Data in table (3) demonstrated that all interactions between tomato cultivars and foliar applications increased fresh and dry weight of plant in the two seasons. Plants of Castle Rock cv. treated with boron foliar application 
had the heaviest fresh and dry weight followed by calcium application and the least one was untreated of Super Strain-B (control). Similar results were obtained by Abd El-Aziz (1997); Fathy et al. (2000); Eata (2001); Hanafy Ahmed et al. (2007); Wanas (2007) and Abd-El-All (2009).

Table (3): Effect of interactions between tomato cultivars and foliar applications on vegetative growth during 2007 (S1) and 2008 (S2) summer seasons.

\begin{tabular}{|c|c|c|c|c|c|c|c|c|c|c|c|}
\hline & \multicolumn{2}{|c|}{$\begin{array}{l}\text { Plant height } \\
\text { (cm) }\end{array}$} & \multicolumn{2}{|c|}{$\begin{array}{c}\text { No.of leaves/ } \\
\text { plant }\end{array}$} & \multicolumn{2}{|c|}{$\begin{array}{c}\text { No.of } \\
\text { branches/ } \\
\text { plant }\end{array}$} & \multicolumn{2}{|c|}{$\begin{array}{c}\text { Fresh } \\
\text { weight(gm) }\end{array}$} & \multicolumn{2}{|c|}{$\begin{array}{c}\text { Dry } \\
\text { weight(gm) }\end{array}$} \\
\hline & & $\mathrm{S} 1^{*}$ & S2 & S1 & S2 & S1 & S2 & S1 & S2 & S1 & S2 \\
\hline \multirow{8}{*}{ 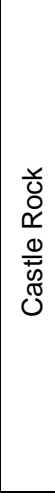 } & $\begin{array}{l}\text { Ca at } 2000 \\
\mathrm{mg} / \mathrm{l}\end{array}$ & 66.66 & 68.33 & 116.16 & 120.00 & 13.33 & 14.33 & 515.00 & 548.33 & 93.98 & 98.67 \\
\hline & \begin{tabular}{|l|}
$\mathrm{Mg}$ at 2000 \\
$\mathrm{Mg} / \mathrm{l}$
\end{tabular} & 65.33 & 67.00 & 113.00 & 116.00 & 11.66 & 14.00 & 422.50 & 458.00 & 81.67 & 88.37 \\
\hline & \begin{tabular}{|l}
$\mathrm{Zn}$ at 100 \\
$\mathrm{Mg} / \mathrm{l}$
\end{tabular} & 63.33 & 65.00 & 108.75 & 108.00 & 12.66 & 13.66 & 420.16 & 430.00 & 73.96 & 74.42 \\
\hline & $\begin{array}{l}\mathrm{B} \text { at } 50 \\
\mathrm{mg} / \mathrm{l}\end{array}$ & 68.50 & 70.66 & 117.66 & 117.50 & 13.66 & 15.00 & 568.08 & 579.66 & 95.37 & 99.16 \\
\hline & $\begin{array}{l}\text { Se at } 50 \mathrm{mg} \\
+V . E 150 \mathrm{~m} \\
\end{array}$ & 67.00 & 67.33 & 114.25 & 110.50 & 13.00 & 14.60 & 444.66 & 466.66 & 89.54 & 90.82 \\
\hline & $\begin{array}{l}\text { Yeast at } \\
100 \mathrm{ml} / \mathrm{l}\end{array}$ & 64.50 & 65.00 & 106.00 & 108.25 & 11.66 & 12.33 & 416.66 & 420.83 & 70.02 & 71.59 \\
\hline & $\begin{array}{l}\text { SA at } 100 \\
\mathrm{mg} / \mathrm{l}\end{array}$ & 71.00 & 71.16 & 127.50 & 128.25 & 13.00 & 14.33 & 515.00 & 526.66 & 90.07 & 92.40 \\
\hline & control & 63.00 & 3.66 & \begin{tabular}{|l|}
104.41 \\
\end{tabular} & \begin{tabular}{|l|}
106.00 \\
\end{tabular} & 11.50 & 12.00 & 407.83 & 419.16 & 69.36 & 71.08 \\
\hline \multirow{8}{*}{ 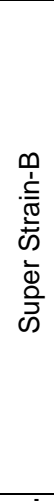 } & $\begin{array}{l}\text { Ca at } 2000 \\
\mathrm{mg} / \mathrm{l}\end{array}$ & 71.33 & 73.33 & 111.33 & 116.00 & 12.66 & 13.00 & 421.87 & 432.50 & 87.61 & 89.87 \\
\hline & \begin{tabular}{|l|}
$\mathrm{Mg}$ at 2000 \\
$\mathrm{mg} / \mathrm{l}$
\end{tabular} & 70.33 & 71.16 & 112.58 & 115.24 & 12.66 & 13.00 & 391.25 & 391.66 & 79.36 & 83.80 \\
\hline & \begin{tabular}{|l}
$\mathrm{Zn}$ at 100 \\
$\mathrm{mg} / \mathrm{l}$
\end{tabular} & 69.00 & 71.86 & 102.33 & 103.16 & 11.83 & 12.00 & 368.33 & 374.00 & 72.14 & 74.97 \\
\hline & \begin{tabular}{|l} 
B at 50 \\
$\mathrm{mg} / \mathrm{l}$
\end{tabular} & 71.16 & 73.55 & 114.16 & 116.00 & 13.33 & 14.00 & 412.29 & 420.00 & 87.86 & 88.51 \\
\hline & $\begin{array}{l}\text { Se at } 50 \mathrm{mg} \\
+V . E 150 \mathrm{~m} \\
\end{array}$ & 6 & 73.66 & 109.50 & 108.00 & 12.16 & 13.00 & 410.58 & 415.83 & 87.14 & 88.39 \\
\hline & $\begin{array}{l}\text { Yeast at } 100 \\
\mathrm{ml} / \mathrm{l}\end{array}$ & 69.00 & 72.08 & 102.16 & 101.83 & 11.66 & 12.66 & 355.83 & 360.00 & 70.66 & 73.70 \\
\hline & $\begin{array}{l}\text { SA at } 100 \\
\mathrm{mg} / \mathrm{l}\end{array}$ & 73.50 & 74.00 & 122.50 & 122.75 & 13.00 & 13.66 & 416.66 & 415.00 & 84.18 & 84.40 \\
\hline & control & 69.00 & 69.33 & 99.00 & 99.66 & 11.66 & 12.00 & 340.41 & 357.00 & 67.06 & 70.70 \\
\hline \multicolumn{2}{|c|}{ L.S.D. at $5 \%$} & 1.55 & 1.65 & 1.62 & 1.71 & NS & NS & 2.01 & 1.96 & 1.55 & 1.93 \\
\hline
\end{tabular}

*S1: 2007 summer season.

S2: 2008 summer season.

\section{Flowering parameters:}

\section{Effect of cultivars:}

Data presented in table (4) revealed that tomato cultivars were significantly differed between each other in flowering parameters, i.e., number of clusters/plant, number of flowers/plant and fruit set percentage (\%) in both seasons under heat stress conditions. Castle Rock tomato cultivar had the highest number of clusters/plant, number of flowers/plant and 
fruit set percentage (\%) compared with Super Strain-B cultivar. The differences between tomato cultivars in fruit setting under high temperature may be due to their variation in viable pollen grains (Phookan et al., 1997), stigma tube elongation and antheridial cone splitting (Saeed et al., 2007). The number of pollen grains produced by the heat tolerant genotypes were higher than those of sensitive genotypes (Abdelmageed et al., 2003). Also, Rainwater et al. (1996) found that different cultivars of tomato exhibited considerable variation in their sensitivity to heat stress. These results are in harmony with those reported by Phookan et al. (1997); Lohar and Peat (1998); El-Desouky et al. (2000); Saleba et al. (2004); Saeed et al. (2007) and Kabura et al. (2009) who found that tomato cultivars differed in flowering parameters. Also Comlekcioglu and Soylu (2010) reported that the production of seeded fruit (SF) was significantly reduced with high temperature $(\mathrm{HT})$ and the amount of reduction varied among tomato genotypes.

\section{Effect of foliar applications:}

Results in table (4) indicated that all foliar treatments(Ca, Mg, Zn, B, $\mathrm{Se}+\mathrm{VE}$, Yeast and SA) enhanced number of clusters, number of flowers and fruit setting percentage (\%) compared with the control, in the two studied seasons. Plants treated with calcium had the best records as for number of clusters and flowers/plant followed by boron and salicylic acid treatments, whereas boron treatment achieved fruit setting followed by calcium and salicylic acid applications in the two seasons, respectively. Similar results were obtained by Oyewole and Aduayi (1992); Agwah and Mahmoud; (1994 Abd El-Aziz (1997); El-Sheikh (1998); Kalarani et al. (2002); Naresh-Babu (2002); Khedr et al. (2004) on eggplant and Jyolsna and Usha Mathew (2008).

The most noticeable effect of high temperatures on reproductive processes in tomato is the production of an exerted style (i.e., stigma is elongated beyond the anther cone), which may prevent self-pollination (Kinet and Peet, 1997).

Continuous exposure of tomato (Trust) plants to high temperatures has two major effects on pollen grains. First, it reduces the total number of grains and secondly, it leads to a marked reduction in germination and a more moderate reduction in the viability of those grains. The failure of viable pollen grain production under high temperature conditions may also be associated with hindered sugar metabolism. Under heat stress, the concentration of starch and soluble sugar in the pollen grains (and that of sugars in the anther walls) were markedly lower than that under control conditions (Pressman et al., 2002).

The favorable effect of boron on fruit setting under heat stress might be due to its effect on fertilization by increasing the pollen producing capacity of the anthers and pollen grain ability (Agarwala et al., 1981) and affect pollen germination, pollen tube growth and fertilization (Vaughen, 1977). Also, SA stimulates flowering in a range of plants, increases flower life, controls ion uptake by roots and stomatal conductivity (Raskin, 1992 and Bhupinder and Usha, 2003). 
Table (4): Effect of tomato cultivars and foliar applications on flowering and fruit setting percentage during 2007 (S1) and 2008 (S2) umme rseasons.

\begin{tabular}{|c|c|c|c|c|c|c|c|c|c|c|c|}
\hline \multirow{2}{*}{\multicolumn{2}{|c|}{ Treatments }} & \multicolumn{2}{|c|}{$\begin{array}{c}\text { No.of } \\
\text { clusters/plant }\end{array}$} & \multicolumn{2}{|c|}{$\begin{array}{c}\text { No.of } \\
\text { flowers/plant }\end{array}$} & \multicolumn{2}{|c|}{$\begin{array}{c}\text { No.of } \\
\text { Fruits/plant }\end{array}$} & \multicolumn{2}{|c|}{$\begin{array}{c}\text { Fruit setting } \\
\text { (\%) }\end{array}$} & \multicolumn{2}{|c|}{$\begin{array}{l}\text { Total yield } \\
\text { (ton/fed.) }\end{array}$} \\
\hline & & $\mathrm{S1}^{*}$ & S2 & S1 & S2 & S1 & S2 & S1 & S2 & S1 & S2 \\
\hline \multirow{2}{*}{ Cvs. } & Castle Rock & 26.24 & 26.44 & 69.76 & 69.77 & 19.35 & 20.10 & 27.59 & 28.71 & 18.325 & 19.488 \\
\hline & Super Strain-B & 26.01 & 25.66 & 67.52 & 66.50 & 13.55 & 14.71 & 19.86 & 21.96 & 12.450 & 13.740 \\
\hline & L.S.D. at $5 \%$ & 0.17 & 0.65 & 0.55 & 0.39 & 0.26 & 0.39 & 0.20 & 0.30 & 02 & 0.001 \\
\hline \multirow{8}{*}{ 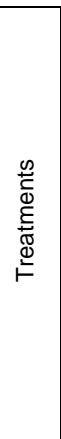 } & $\begin{array}{l}\text { Ca at } 2000 \\
\mathrm{mg} / \mathrm{l}\end{array}$ & 29.24 & 28.45 & 73.74 & 71.66 & 19.38 & 20.00 & 26.22 & 27.85 & 18.942 & 19.770 \\
\hline & \begin{tabular}{|l|}
$\mathrm{Mg}$ at 2000 \\
$\mathrm{mg} / \mathrm{l}$
\end{tabular} & 27.74 & 26.75 & 68.18 & 68.33 & 15.73 & 17.41 & 22.85 & 25.35 & 14.320 & 15.966 \\
\hline & $\begin{array}{l}\mathrm{Zn} \text { at } 100 \\
\mathrm{mg} / \mathrm{l}\end{array}$ & 23.73 & 23.95 & 65.20 & 65.25 & 14.08 & 14.83 & 21.51 & 22.63 & 12.707 & 13.790 \\
\hline & \begin{tabular}{|l|}
$\mathrm{B}$ at 50 \\
$\mathrm{mg} / \mathrm{l}$
\end{tabular} & 28.36 & 28.10 & 73.03 & 70.91 & 19.68 & 20.50 & 26.98 & 28.74 & 19.168 & 20.162 \\
\hline & $\begin{array}{l}\text { Se at } 50 \mathrm{mg} / \mathrm{l} \\
+\mathrm{V} . \mathrm{E} 150 \mathrm{mg} / \mathrm{l}\end{array}$ & 27.10 & 27.16 & 68.63 & 69.50 & 17.23 & 18.58 & 24.81 & 26.70 & 16.102 & 17.806 \\
\hline & $\begin{array}{l}\text { Yeast at } 100 \\
\mathrm{ml} / \mathrm{l}\end{array}$ & 23.20 & 23.50 & 64.96 & 65.75 & 14.01 & 15.33 & 21.36 & 23.21 & 12.794 & 14.413 \\
\hline & $\begin{array}{l}\text { SA at } 100 \\
\mathrm{mg} / \mathrm{l}\end{array}$ & 27.15 & 27.37 & 71.12 & 69.25 & 18.26 & 18.93 & 25.65 & 27.04 & 17.126 & 18.316 \\
\hline & control & 23.00 & 23.12 & 64.25 & 64.41 & 13.20 & 13.66 & 20.46 & 21.16 & 11.941 & 12.689 \\
\hline \multicolumn{2}{|r|}{ L.S.D. at $5 \%$} & 0.95 & 0.94 & 1.12 & 1.09 & 0.79 & 0.86 & 0.62 & 0.68 & 0.008 & .008 \\
\hline
\end{tabular}

${ }^{\star} \mathrm{S} 1: 2007$ summer season.

S2: 2008 summer season.

Effect of interaction between tomato cultivars and foliar applications:

Data in table (5) indicated that the interaction between tomato cultivars and different foliar application take the same trend of foliar applications. In addition, ( $\mathrm{Ca} \times$ Castle Rock) was the best interaction in number of clusters and flowers/plant followed by ( $\mathrm{x} \times$ Castle Rock) in both seasons, whereas ( $\mathrm{B} \times$ Castle Rock) was the superior as for fruit set percentage (\%) followed by ( $\mathrm{Ca} \times$ Castle Rock). These results are in accordance with those obtained by Agwah and Mahmoud (1994); Arisha et al. (1999); El-Ghamriny et al. (1999); Fathy et al. (2000); Eata (2001); Wanas (2007) and Abd-El-All (2009).

\section{Fruit yield:}

\section{Effect of cultivars:}

The results in table (4) showed that there were significant differences between Castle Rock and Super Strain-B cultivars in number of fruits/plant and total yield(ton/fed.). It can be suggested that Castle Rock cv was the superior in number of fruits/plant and total yield(ton/fed.). The differences in yield between tomato cultivars under high temperature conditions may be due to their variation in growth, fruit set and number and weight of fruits/plant. 
Table (5): Effect of interactions between tomato cultivars and foliar applications on flowering and fruit setting percentage during 2007 (S1) and 2008 (S2) summer seasons.

\begin{tabular}{|c|c|c|c|c|c|c|c|c|c|c|c|}
\hline \multirow{2}{*}{\multicolumn{2}{|c|}{ Treatments }} & \multicolumn{2}{|c|}{$\begin{array}{l}\text { No.of } \\
\text { clusters/ } \\
\text { plant }\end{array}$} & \multicolumn{2}{|c|}{$\begin{array}{l}\text { No.of } \\
\text { flowers/ } \\
\text { plant }\end{array}$} & \multicolumn{2}{|c|}{$\begin{array}{l}\text { No.of } \\
\text { Fruits/ } \\
\text { plant }\end{array}$} & \multicolumn{2}{|c|}{$\begin{array}{l}\text { Fruit setting } \\
(\%)\end{array}$} & \multicolumn{2}{|c|}{$\begin{array}{l}\text { Total yield } \\
\text { (ton/fed.) }\end{array}$} \\
\hline & & $\mathrm{S} 1^{*}$ & S2 & S1 & S2 & S1 & S2 & S1 & S2 & S1 & S2 \\
\hline \multirow{8}{*}{ 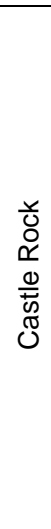 } & $\begin{array}{l}\mathrm{Ca} \text { at } 2000 \\
\mathrm{mg} / \mathrm{l}\end{array}$ & 28.60 & 28.75 & 72.66 & 73.33 & 22.16 & 22.66 & 30.49 & 30.93 & 22.141 & 22.788 \\
\hline & \begin{tabular}{|l|}
$\mathrm{Mg}$ at 2000 \\
$\mathrm{mg} / \mathrm{l}$
\end{tabular} & 27.95 & 27.50 & 71.70 & 70.33 & 19.46 & 20.50 & 27.14 & 29.12 & 18.116 & 19.180 \\
\hline & $\begin{array}{l}\mathrm{Zn} \text { at } 100 \\
\mathrm{mg} / \mathrm{l}\end{array}$ & 23.73 & 24.41 & 66.73 & 67.00 & 16.50 & 17.33 & 24.72 & 25.86 & 14.987 & 16.264 \\
\hline & $\begin{array}{l}\mathrm{B} \text { at } 50 \\
\mathrm{mg} / \mathrm{l}\end{array}$ & 28.33 & 28.20 & 72.16 & 72.00 & 22.20 & 23.16 & 30.76 & 32.18 & 21.928 & 23.160 \\
\hline & $\begin{array}{l}\text { Se at } 50 \\
\mathrm{mg} / \mathrm{l}+\mathrm{V} . \mathrm{E} \\
15 \mathrm{mg} / \mathrm{l}\end{array}$ & 27.93 & 27.83 & 71.20 & 71.00 & 20.80 & 21.33 & 28.94 & 30.11 & 19.412 & 20.748 \\
\hline & $\begin{array}{l}\text { Yeast at } \\
100 \mathrm{ml} / \mathrm{l}\end{array}$ & 23.26 & 23.66 & 66.26 & 67.50 & 16.53 & 18.00 & 24.93 & 26.66 & 15.316 & 17.248 \\
\hline & $\begin{array}{l}\text { SA at } 100 \\
\mathrm{mg} / \mathrm{l}\end{array}$ & 27.23 & 27.91 & 71.36 & 71.50 & 21.73 & 22.00 & 30.46 & 30.70 & 20.548 & 21.428 \\
\hline & control & 22.93 & 23.25 & 6.00 & 65.50 & 15.40 & 15.83 & 23.33 & 24.17 & 14.145 & 15.088 \\
\hline \multirow{8}{*}{ 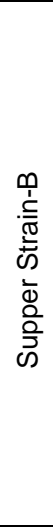 } & $\begin{array}{l}\text { Ca at } 2000 \\
\mathrm{mg} / \mathrm{l}\end{array}$ & 29.88 & 28.16 & 74.81 & 70.00 & 16.60 & 17.33 & 21.96 & 24.77 & 15.740 & 16.752 \\
\hline & $\begin{array}{l}\text { Mg at } 2000 \\
\mathrm{mg} / \mathrm{l}\end{array}$ & 26.53 & 26.00 & 64.66 & 66.33 & 12.00 & 14.33 & 18.56 & 21.59 & 10.524 & 12.752 \\
\hline & $\begin{array}{l}\mathrm{Zn} \text { at } 100 \\
\mathrm{mg} / \mathrm{l}\end{array}$ & 23.73 & 23.50 & 63.66 & 63.50 & 11.66 & 12.33 & 18.31 & 19.41 & 10.426 & 11.316 \\
\hline & $\begin{array}{l}\mathrm{B} \text { at } 50 \\
\mathrm{mg} / \mathrm{l}\end{array}$ & 28.40 & 28.00 & 73.90 & 69.83 & 17.16 & 17.83 & 23.21 & 25.30 & 16.408 & 17.164 \\
\hline & $\begin{array}{l}\text { Se at } 50 \\
\mathrm{mg} / \mathrm{l}+\mathrm{V} . \mathrm{E} \\
15 \mathrm{mg} / \mathrm{l}\end{array}$ & 26.26 & 26.50 & 66.06 & 68.00 & 13.66 & 15.83 & 20.67 & 23.28 & 12.792 & 14.864 \\
\hline & $\begin{array}{l}\text { Yeast at } \\
100 \mathrm{ml} / \mathrm{l}\end{array}$ & 23.13 & 23.33 & 63.66 & 64.00 & 11.50 & 12.66 & 17.78 & 19.77 & 10.273 & 11.577 \\
\hline & $\begin{array}{l}\text { SA at } 100 \\
\mathrm{mg} / \mathrm{l}\end{array}$ & 27.08 & 26.83 & 70.88 & 67.00 & 14.80 & $15 . .86$ & 20.84 & 23.39 & 13.703 & 15.205 \\
\hline & control & 23.06 & 23.00 & 62.50 & 63.33 & 11.00 & 11.50 & 17.59 & 18.15 & 9.737 & 10.289 \\
\hline $\mathbf{L}$ & S.D. at $5 \%$ & NS & NS & 1.58 & 1.55 & 1.11 & 1.22 & 0.88 & 0.97 & 0.005 & 0.004 \\
\hline
\end{tabular}

*S1: 2007 summer season.

S2: 2008 summer season.

\section{Effect of foliar applications:}

Results in table (4) show that all foliar applications (Ca, Mg, Zn, B, $\mathrm{Se}+\mathrm{VE}$, Yeast and SA) significantly increased number of fruits/plant and total yield(ton/fed.). The highest number of fruits and total yield(ton/fed.) were obtained when tomato plants treated with $B$ foliar application followed by $\mathrm{Ca}, \mathrm{SA}, \mathrm{Se}+\mathrm{VE}$, respectively in both seasons. These results are harmony with those reported by Hao-Xiuming and Papadopoulos (2004); ElMansi et al. (2005); Haque et al. (2006); Lee GuangJae et al. (2007); Kamal and Abd Al-Gaid (2008); Patil et al. (2008) and Yildirim and Dursun (2009). 
Effect of interaction between tomato cultivars and foliar applications:

Data in table (5) showed that all the interactions between tomato cultivars and foliar applications increased number of fruits/plant and total yield(ton/fed.). It is evident that plants of Castle Rock cv treated with boron and calcium were the most superior applications on number of fruits/plant and total yield(ton/fed.) in the two studied seasons. These results are in line with those obtained by Agwah and Mahmoud (1994); Arisha et al. (1999); ElGhamriny et al. (1999); Eata (2001); Hanafy Ahmed et al. (2007); Wanas (2007) and Abd-El-All (2009). It's obviously that the highest yield of the two cultivars was related to the number of clusters, number of flowers and fruit set percentage under high temperature conditions.

\section{CONCLUSION}

It can be concluded that sprayed Castle Rock cv plants with boron at $50 \mathrm{mg} / \mathrm{L}$, calcium at $2000 \mathrm{mg} / \mathrm{L}$, salicylic acid at $100 \mathrm{mg} / \mathrm{L}$ and selenium at concentration of $50 \mathrm{mg} / \mathrm{L}$ mixed with vitamin $E$ at concentration of $150 \mathrm{mg} / \mathrm{L}$ as foliar application three times, i.e., 15 days after transplanting then repeated each 15 days interval improve tomato vegetative growth, flowering and fruit yield(ton/fed.) under high temperature conditions jn summer season.

\section{REFRENECES}

Abd-El-All, M.M.M. (2009). Improvement of tomato productivity by using certain natural materials. Ph.D.Thesis, Dep.of Agric.Botany, Faculty of Agric.Benha Univ.Egypt.

Abdel-Aziz, M.A. (1997). Response of tomato plants to nitrogen fertilizer levels and growth regulators. M.Sc.Thesis, Dept.of Vegetable Crops, Faculty of Agric.Cairo Univ.Egypt.

Abdelmageed, A.H.; N. Gruda and B. Geyer (2003). Effect of High Temperature and Heat Shock on Tomato (Lycopersicon esculentum Mill.) Genotypes under Controlled Conditions. Conference on International Agricultural Research for Development, Göttingen, October 8-10, 2003.

Abou-Aly, H.E. (2005). Stimulatory effect of some yeast applications on response of tomato plants to inoculation with biofertilizers. Annals of Agricultural Science, Moshtohor, 43(2):595-609.

Agarwala, S.C.; P.N. Chatterijee and C.P. Sharma (1981). Development and enzymatic changes during pollen development in boron deficient maize plants. J.Plant Nutt., 3:329-336.

Agwah, E.M.R. and H.A.F. Mahmoud (1994). Effect of some nutrients, sucrose and cultivars on tomato fruit set and yield. Bull.Fac.Agric.Univ.Cairo, 45:137-148.

Albert, L.S. (1965). Ribonucleic content, boron deficiency symptoms and elongation of tomato root tips. Plant Physiol., 40:649-652.

Albert, L.S. and C.M. Wilson (1961). Effect of boron on elongation of tomato tips. Plant Physiol., 36:244-251. 
Amer, A.S.S. (1981). Effect of some growth regulators and some minor elements on growth and yield of tomato. M.Sc.Thesis, Hort.Dep., Fac.of Agric.Sci., Moshtohor, Zagazig University.

Arisha, H.M.E.; E.A. El-Ghamriny and K.A. Nour (1999). Studies on tomato flowering, fruit set, yield and quality in summer season. 2- Spraying with boron, zinc and phosphorus. Zagazig J.Agric.Res., 26 (5):13651384.

Bhupinder, S. and K. Usha (2003). Salicylic aciud induced physiological and biochemical changes in wheat seedlings under water stress. Plant Growth Regul., 39: 137-141.

Brown, P.H.; I. Cakmak and Q. Zhang (1993). Zinc in soils and plants-form and function of zinc in plants. Kluwer Aca.Pub.pp. 93-105.

Comlekcioglu, N. and M.K. Soylu (2010). Determination of high temperature tolerance via screening of flower and fruit formation in tomato. YYU J. AGR. SCI., 20(2):123-130.

Dicknson, C.D.; T. Altabellaand; M.J. Chrispeels (1991). Slow growth phenotype of transgenic tomato expressing apoplastic invertase. Plant physiol., 95: 420-425.

Domingo, A.L.; Y. Nagatomo; M. Tamai and H. Takaki (1990). Indole carboxylic acid in zinc-deficient radish shoots. Soil Sci.Plant Nutri., 36:555-560.

Eata, A.E.M. (2001). Response of some tomato cultivars to natural soil salinity and use of some treatments to reduce salt injury. Ph.D.Thesis Dept.of Veg. and Floric.Fact.Agric.Mansoura Univ.Egypt.

El-Desouki, S.A.; El-S, L., El-S. Fathy and S. Farid (2000). High temperature tolerability in tomato: Evaluation of some genotypes for late summer plantings.Annals of Agric.Sc., Moshtohor, 38(1):179-197.

El-Ghamriny, E.A.; H.M.E. Arisha and K.A. Nour (1999). Studies on tomato flowering, fruit set, yield and quality in summer season. 1- Spraying with thiamine, ascorbic acid and yeast. Zagazig J.Agric.Res., 26 (5):1345-1364.

El-Mansi, A.A.; A. Bardisi; H.M. Arisha and M.M. El-Robae (2005). Nitrogen soil application combined with calcium foliar application on tomato under sandy soil conditions. 2. Effect on cracking and blossom end rot. The 6 th Arabian Conference for horticulture, Ismailia, Egypt, 191-204.

El-Sheikh, T.M. (1998). Physiological studies on yield, quality and toragebility of tomato fruits. Annals of Agricultural Science, Moshtohor, 36(1):513526.

Fathy, El-S.L.El-s; S. Farid and S.A. El-Desouky (2000). Induce cold tolerance of outdoor tomatoes during early summer season by using triphosphate (ATP), yeast, other natural and chemical treatments to improve their fruiting and yield. J.Agric.Sci.Mansoura Univ., 25 (1):377401.

Glala, A.A.; A.M. Hoda and Z.F. Fawzi (2005). Improving tomato plant growth, health, earliness, productivity and fruit quality by chemically induced systematic resistance. Journal of Applied Sciences Research, 1 (5): 362-372. 
Gomez, K.A. and A.A. Gomez (1984). Statistical Procedures for the Agricultural Researches. John Wiley and Son, Inc.New York., P. 139 153

Hamsaveni, M.R.; M.B. Kurdikeri; M. Shekhargouda; S.D. Shashidhara and P.R. Dharmatti (2003). Effect of gypsum and boron on seed yield and quality on tomato cv. Megha . Karnataka Journal of Agricultural Sciences, 16(3): 457-459.

Hanafy Ahmed, A.H.; M.K. Khalil; A.M. Metwally and M.A. Abdel-Aziz (2007). Effecet of biomagic, yeast, Acadian sea plants, foliafeed $d$, trial compound fertilizer, putrescine and silicon treatments on growth, yield and chemical composition of tomato plants grown under early and late summer seasons. J.Agric.Sci.Mansoura Univ., 32 (2):913-949.

Hao-XiuMing and A.P. Papadopoulos (2004). Effects of calcium and magnesium on plant growth, biomass partitioning, and fruit yield of winter greenhouse tomato. HortScience, 39 (3): 512-515.

Haque, M.A.; R. Sen; R. Gomes; Selim-Ahmed; M.N. Anwar (2006). Effect of magnesium on different tomato varieties in Tista Meander Floodplain Soil of Rangpur District in Bangladesh. International Journal of Sustainable Agricultural Technology, 2 (6): 14-17.

Hess, J.L. (1983). Vitamin E, a-Tochopherol. In: antioxidants in higher plants. R.G., Alscher \& G.L., Hess (Eds.). CRC press, Inc., Boca Raton., 111-134.

Howarth, C.J. (2005). Genetics improvements of tolerance to high temperature. In: Ashraf, M., Harris, P.J.C.(Eds.), A biotic stresses : plant resistance through breeding and molecular approaches. Howarth Press Inc., New York.

Jayakumar, J.; G. Rajendran and S. Ramakrishnan (2006). Evaluation of salicylic acid as a systemic resistance inducer against Meloidogyne incognita on tomato cv. Co3. Indian Journal of Nematology, 36(1): 7780.

Jiang, Y. and B. Huang (2001). Plants and the environment. Effect of calcium on antioxidant activities and water relations associated with heat tolerance in two cool-season grasses. Journal Oxford: 52 (355):341.

Jyolsna, V. K. and Usha Mathew (2008). Boron nutrition of tomato (Lycopersicon esculentum L.) grown in the laterite soils of southern Kerala. Journal of Tropical Agriculture. 46: 1/2, 73-75.

Kabura, B.H.; P.E. Odo and A. Abubakar (2009). Performance of Some Tomato (Lycopersicon esculentum Mill.) Varieties under Heat Period in Northern Nigeria. Journal of Agronomy, 8 (1): 45-48.

Kalarani, M.K.; M. Thangaraj; R. Sivakumar; V. Mallika (2002). Effects of salicylic acid on tomato (Lycopersicon esculentum Mill) productivity. Crop Research, 23(3): 486-492.

Kamal, A.M. and M.A. Abd Al-Gaid (2008). Enhancing tomato fruits yield and quality using foliar spray with calcium. J.Agric.Sci.Mansoura Univ., 33 (12): 8723-8733. 
Karadeniz, F.; H.S. Burdurlu and Y. Soyer (2005). Antioxidant activity of selected fruits and vegetables grown in turkey. Turk.J.Agric., 29: 297303.

Khedr, Z.M.A. and S. Farid (2000). Response of naturally virus infectedtomato plants to yeast extract and phosphoric acid application. Annals of Agric. Sci. Moshtohor, 38(2): 927-939.

Khedr, Z.M.A.; El-S.El-S. Fathy and A.M. Moghazy (2004). Effect of some nutrients and growth substances on productivity of eggplant (Solanum melogena var esculenta) growing under high temperature conditions. Annals of Agric.Sci.Moshtohor, 42(2): 583-602.

Kinet, J. M. and M. M. Peet (1997). Tomato. In: Wien, H.C. (Ed.), The Physiology of Vegetable Crops. CAB International, Wallingford, UK, pp. 207-258.

Klessige, D.F. and J. Malamy (1994). The salicylic acid signal in plants. Plant Mol.Biol., 26:1439.

Larkindale, J. and M.R. Knight (2002). Protection against heat stress-induced oxidative damage in arabidopsis involves calcium, abscisic acid, ethylene and salicylic acid. Plant Physiol, 128: 682-695.

Lee GuangJae, Kang BoKu, Kim Taell, Kim TaeJung and Kim JinHan (2007). Effects of different selenium concentrations of the nutrient solution on the growth and quality of tomato fruit in hydroponics. Acta Horticulture, 761:443-448.

Lohar, D.P. and W.E. Peat (1998). Floral characteristics of heat-tolerant and heat-sensitive tomato (Lycopersicon esculentum Mill.) cultivars at high temperature. Scientia Horticult., 73(1):53-60.

Manoj-Raghav and R.D. Sharma (2003). Growth and yield in tomato-okravegetable pea cropping sequence as affected by levels and methods of zinc application. Progressive-Horticulture, 35(1): 96-99.

Nagodawithana, W.T. (1991). Yeast technology. Universal Foods Corporation Milwaukee, Wisconsin. Published by Van Nostrand Reinhold, New York, 273 P.

Naresh-Babu (2002). Response of foliar application of boron on vegetative growth, fruit yield and quality of tomato var. Pusa Ruby. Indian Journal of Hill Farming., 15(1): 109-112.

Oyewole, O.I. and E.A. Aduayi (1992). Evaluation of the growth and quality of the "Ife Plum" tomato as affected by boron and calcium fertilization. Journal of Plant Nutrition, 15(2): 199-209.

Oyinlola, E.Y.(2004). Response of irrigated tomatoes (Lycopersicon lycopersicum Karst) to boron fertilizer: 2. Growth and nutrient concentration. Nigerian Journal of Soil Research, 5: 62-68.

Palta, J.P. (1990). Stress interactions at the cellular and membrane levels. Hortscience, 25(11):1377-1381.

Patil, B.C.; R.M Hosamani; P.S. Ajjappalavara; B.H. Naik; R.P. Smitha and K.C. Ukkund (2008). Effect of foliar application of micronutrients on growth and yield components of tomato (Lycopersicon esculentum Mill). Karnataka J.Agric.Sci., 21(3): 428-430. 
Phookan, D.B.; A. Shadeque and B.K. Chakravarty (1997). Sensivity of tomato (Lycopersicon esculentum) cultivars to high-temperature pollination and fruit-set under plastic rain shelter. Indian Jornal of Agricultural Sciences, 67 (8):312-313.

Pressman, E.; M.M. Peet and D.M. Pharr (2002). The effect of heat stress on tomato pollen characteristics is associated with changes in carbohydrate concentration in the developing anthers. Annals of Botany, 90:631-636.

Raskin, I. (1992). Role of salicylic acid in plants. Ann. Rev. Plant Physiol. Mol. Biol., 43: 439- 463.

Rainwater, D. T.; D. R. Gossett; E. P. Mollhollon; H. Y. Hanna; S. W. Banks and M. C. Lucas (1996). The relationship between yield and the antioxidant defense system in tomatoes grown under heat stress. Free Radical Research, 25:421-435.

Rivero, R.M.; J. M. Ruiz and L. Romero (2004). oxidative metabolism in tomato plants subjected to heat stress.Journal of Horticult. Sci. and Biotec., 49(4): 560-564.

Saeed, A.; K. Hayat; A.A. Khan and S. Iqbal (2007). Heat Tolerance Studies in Tomato (Lycopersicon esculentum Mill.). Int. J. Agri. Biol., 9( 4): 649652.

Saleba, F.S.; M.H. Zaky and A.M. Hewedy (2004). Genetical studies on some tomato cultivars under high temperature condition. I: Inheritance studies of some characters in tomato under high temperature conditions. J.Agric.Sci.Mansoura Univ., 29 (11):6491-6506.

Sarin, M.N. and A. Sadgopal (1967).Studies on the effect of boron deficiency in tomato seedlings. I. Growth and histophysiological responses. Indian J.PI. Physiol., 10:142-153.

Schöffi, F.; R. Prandl and A. Reindl (1999). Molecular responses to heat stress. In: Shinozaki, K., Yamaguchi-Shinozaki, K. (Eds.), Molecular Responses cold, drought, heat and salt stress in higher plants, R.G.Landes co., Austin, Texas, pp.81-98.

Shang QingMao, Chen ShuFang and Zhang ZhiGang (2005). Regulation of selenium on antioxidative enzymes activity in pepper leaves under high temperature stress. Acta Horticulture Sinica. Chinese Society for Horticulture Science, Beijing, China :2005. 32:1, 35-38. 11 ref.

Snedecor, G.W. and W.G. Cochran (1968). Statistical Methods. Lowa state.Univ.Press, Ame., USA, 6th Ed., 393 P.

Soylu, M.K. and N. Çömlekçioğlu (2009). The effects of high temperature on pollen grain characteristics in tomato (Lycopersicon esculentum M.). J.Agric.Fac.HR.U., 13(2): 35- 42.

Vaughen, A.K.F. (1977). The relation between the concentration of boron in the reproductive and vegetative organs of maize plants and their development. Rhod.J.Agric.Res., 15:163-170.

Wanas, A.L. (2007). Trials for improving growth and productivity of tomato (Lycopersicon esculentum, Mill.) plants grown in winter season. J. Agric. Sci. Mansoura Univ., 32 (2): 991-1009.

Weiderrecht, G.; D. Seto and C.S. Parker (1988). Cell. Cambridge Mass, $54: 841-853$ 
Yadav, P.V.S.; Abha-Tikkoo and N.K. Sharma (2001).Effect of zinc and boron application on growth, flowering and fruiting of tomato (Lycopersicon esculentum Mill). Haryana. Journal of Horticult. Sci., 30(1/2): 105-107.

Yildirim, E. and A. Dursun (2009). Effect of foliar Salicylic acid application on plant growth and yield of tomato under greenhouse conditions. Acta Hort. (ISHS), 807: 395-400.

بعضض الممارسـات الزراعيـة لتحسين إنتاجيـة الطمـاطم تحست ظـروف العـرارة المرتفعة العندار

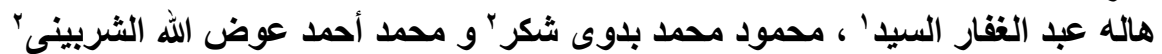

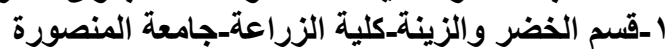

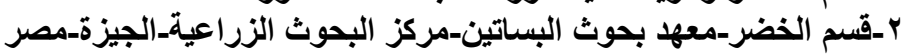

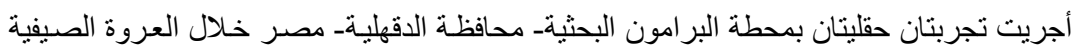

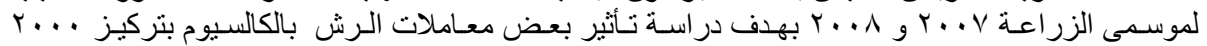

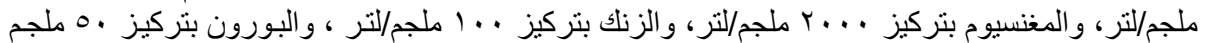

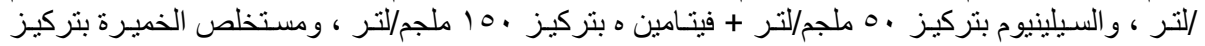

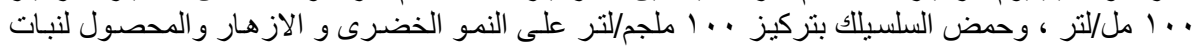

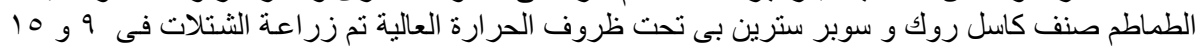
مايو فى موسمى التجربة على الترتيب.

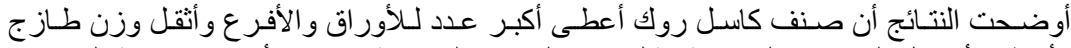

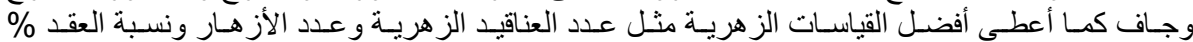

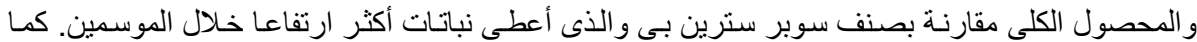

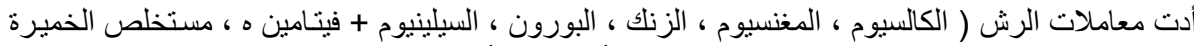

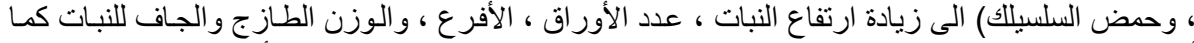

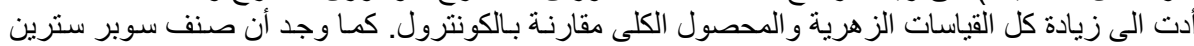

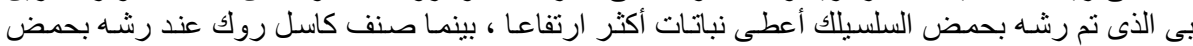

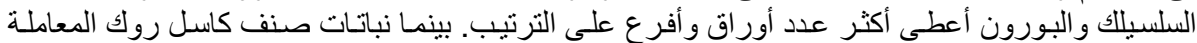

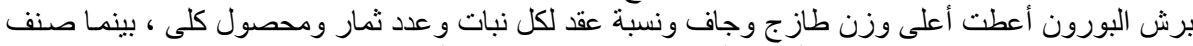

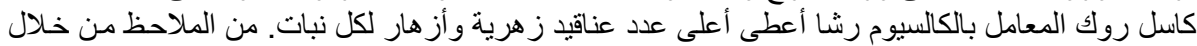

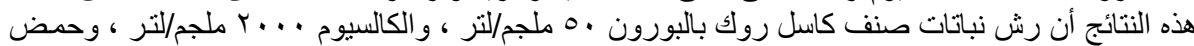

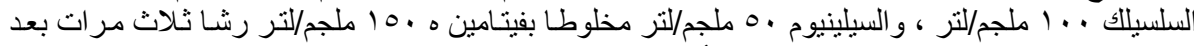

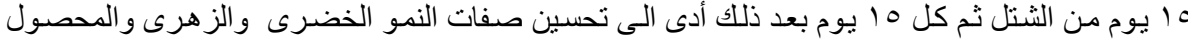

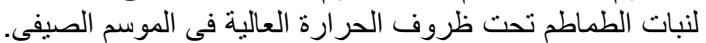

كلية الزراعة - جامعة المنصورة كلية الزراعة - جامعة الأسكندرية
قام بتحكيم البحث

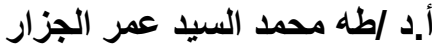

أ.د / سناء مرسى مصطفى العربى الجيى 